\title{
Maxillary total arch distalization using midpalatal mini-implant: Case report
}

\author{
Chang-Bok Song ${ }^{1}$ and Sung-Hoon Lim $^{1,2 *}$ \\ ${ }^{1}$ Department of Orthodontics, School of Dentistry, Chosun University, Gwangju 61452, Republic of Korea \\ ${ }^{2}$ Oral Biology Research Institute, Chosun University, Gwangju 61452, Republic of Korea
}

(Received Jul 13, 2017; Revised version received Aug 25, 2017; Accepted Aug 28, 2017)

\begin{abstract}
Orthodontic mini-implant is usually placed in the buccal interdental area for molar distalization or total arch distalization. However, this requires timely replacement of the mini-implant to prevent contact between root and mini-implant and ensuing root resorption. Alternatively, midpalate may be considered as the mini-implant placement site because it has considerably dense bone and there is no interference with roots. Also, distalization forces may be designed to pass through the center of resistance of dentition for translatory distal movement. In this case report, end-on Class II occlusion with lip protrusion was successfully treated by applying distal forces from a transpalatal arch to a lever attached to two midpalatal mini-implants. Anti-rotation bends were bent on transpalatal arch to prevent mesial rotation of first molars during distalization. Another benefit of this approach is that molar distalization may be initiated at the beginning of treatment because distal tipping of molars can be prevented by applying distal force at the level of the center of resistance of molars thus eliminating the need of stiff rectangular archwire. With this approach, time-consuming molar distalization may be initiated at the beginning of treatment and therefore, overall treatment duration can be reduced.
\end{abstract}

KEY WORDS: Distalization, Mini-implant, Midpalate, Transpalatal arch

\section{서 론}

II급 구치관계를 가지는 총생 환자의 비발치 치료는 상 악 구치의 후방 이동에 의해서 치료하는 것이 전치의 전 방 경사를 막고 구순 돌출을 개선하여 조화로운 측모를 얻 기 위한 바람직한 방법이 될 수 있다[1,2]. 이를 위해서 미 니-임플랜트를 이용하여 구치부만 후방 이동 시키는 다양 한 방법들이 개발되어 왔다[3-5].

상악 구치 후방 이동 시 고려사항으로 제3대구치 유무 및 후방 이동 경로에 포함되는 치조골에 대한 평가가 필 요하다. 제 3 대구치의 위치와 크기가 적절하다면 제 2 대구 치를 발치하고 제 1 대구치를 후방 이동시키는 것이 효율적 이며[6], 그렇지 않다면 구치 후방 이동 직전에 제3대구치 를 발치하는 것이 치아 이동속도를 증대시키는 방법이 된 다. 또한 $\mathrm{CBCT}$ 이미지를 통해 대구치 부위 치조골에서

*Corresponding author: Sung-Hoon Lim

Department of Orthodontics, School of Dentistry, Chosun University, 309 Pilmun-daero, Dong-gu, Gwangju 61452, Republic of Korea

Tel.: +82-62-220-3870

E-mail: shlim@chosun.ac.kr
치근과 피질골의 간격을 평가하여 바람직한 후방 이동 방 향을 결정할 수 있다[7].

상악 구치의 후방 이동을 위해서는 협측 치조골에 미니-임 플랜트를 식립하는 것이 일반적이다. 하지만 이 경우 미니임플랜트와 치근의 간섭으로 인해 많은 양의 치근 후방 이 동을 얻기 위해서는 재식립이 필요할 수 있으며, 견고한 호 선이 장착된 이후에 후방력을 적용할 수 있다는 단점이 있 다[8]. 하지만 정중구개부는 특별한 해부학적 구조물이 존재 하지 않아 손상 위험이 없고 조직학적으로 각화치은으로 덮 여 있어 미니-임플랜트 주위 연조직의 염증 발생 가능성이 낮으며 두꺼운 치밀뼈로 구성되어 미니-임플랜트를 식립하 기에 유리한 부위이다[9]. 본 증례 보고에서는 정중구개부에 식립한 미니-임플랜트와 레버를 이용하여 상악 전치열을 성 공적으로 후방 이동시킨 증례를 소개하고자 한다.

\section{증례 보고}

\section{진단}

19세 여자 환자가 “치아가 비뚤비뚤하고 입이 나왔어요." 라는 주소로 본원에 내원하였다. 안모사진에서 hypermentalis 


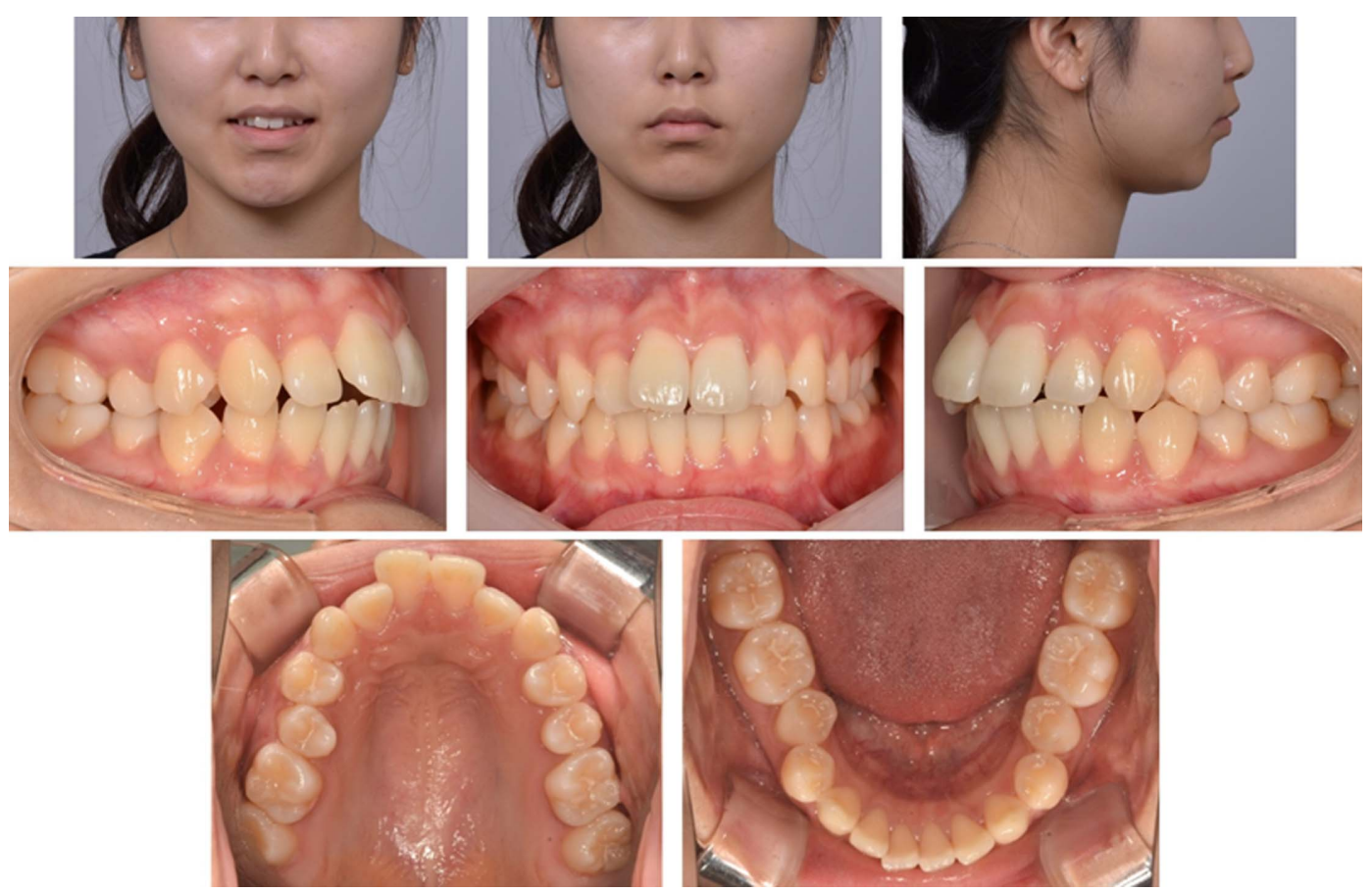

Fig. 1. Pretreatment facial and intraoral photographs.
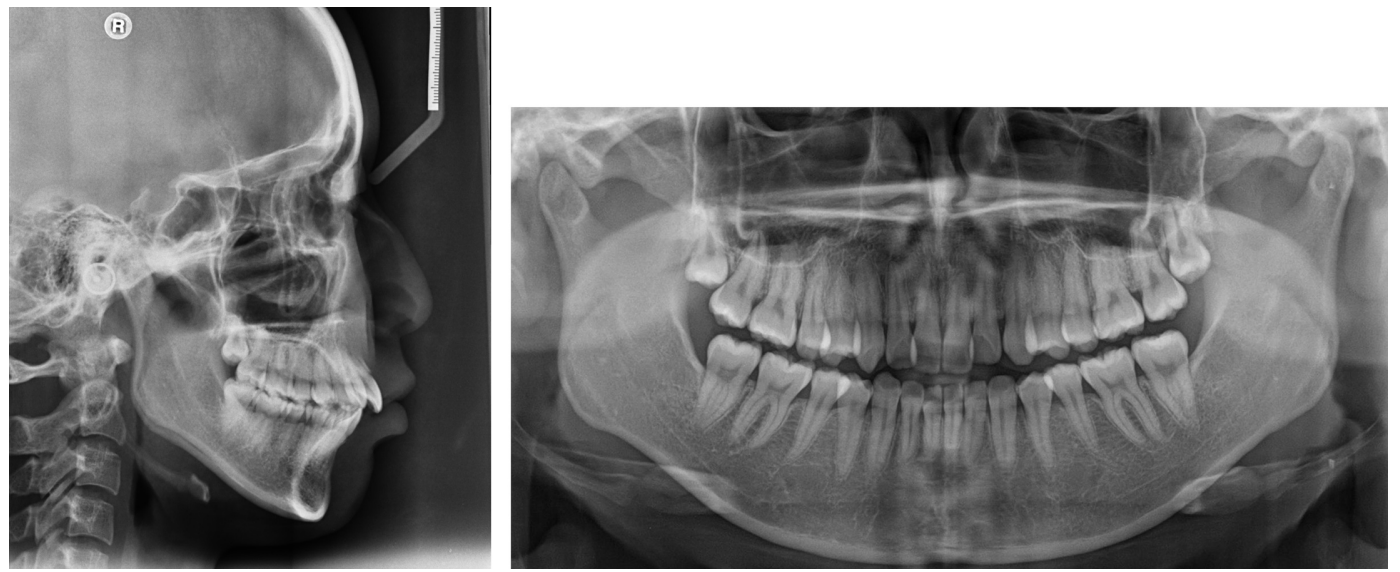

Fig. 2. Pretreatment lateral cephalometric radiograph and panoramic radiograph.

activity가 관찰되었고 볼록한 측모를 보였다. 구치관계는 우측에서 $3 \mathrm{~mm}$ 의 Class II, 좌측에서 $2 \mathrm{~mm}$ 의 Class II 관 계를 보였으며 상악 중절치의 순측 경사로 $5 \mathrm{~mm}$ 의 수평 피개를 가지는 II급 1 류 부정교합 양상을 보였다. 상하악 모두에 스피만곡이 있었고, 전치부 교합 접촉은 없었다 (Fig. 1). 상하악 모두 $2.5 \mathrm{~mm}$ 정도의 공간부족을 보였고, 전치부 Bolton ratio는 74.4\%로 정상 범주보다 작았다. 측 모두부계측 방사선사진을 분석한 결과 $\mathrm{SNA} 79.5^{\circ}, \mathrm{SNB}$ $74.6^{\circ}, \mathrm{ANB} 4.9^{\circ}$ 로 골격성 I급 관계였으나, 하악이 다소 후퇴된 경향을 보였다. 상악 전치 치축은 순측경사를 보였 으나 정상 범주 내에 있었고, 하악 전치 치축은 순측경사 되어 있었다. 심미선에 대해서 상하순은 모두 전방 위치되어
있었다(Fig. 2, Table 1). 파노라마 사진에서 특이할 만한 소견 은 없었고, 상악 앙쪽 제 3 대구치가 맹출 중이었다(Fig. 2).

\section{치료 계획}

상악 전치열의 후방 이동을 통해 구순 돌출 및 II급 구 치관계를 개선하기로 하였다. 제 3 대구치가 맹출 중이었기 때문에 상악 구치 후방 이동을 위해 제 2 대구치 발치를 고 려하였다. 하지만 $\mathrm{CBCT}$ 촬영 결과, 제 3 대구치가 제 2 대구 치에 비해 치관 크기가 왜소하다고 판단되어 제3대구치를 발치하기로 하였다(Fig. 3). 상악 구치의 후방 이동은 정중 구개부에 미니-임플랜트를 식립하고 레버를 장착한 후, 횡 구개호선과 탄성 체인을 연결하여 후방력을 적용하기로 
Table 1. Cephalometric measurements

\begin{tabular}{lrccc}
\hline Measurement & Norm & Pretreatment & Posttreatment Difference \\
\hline SNA $\left(^{\circ}\right)$ & 81.1 & 79.5 & 79.6 & 0.1 \\
SNB $\left(^{\circ}\right)$ & 78.0 & 74.6 & $74.1^{*}$ & -0.5 \\
ANB $\left(^{\circ}\right)$ & 3.5 & 4.9 & $5.5^{*}$ & 0.6 \\
FMA $\left(^{\circ}\right)$ & 29.6 & 32.4 & 33.0 & 0.6 \\
U1 to SN $\left(^{\circ}\right)$ & 105.3 & 108.2 & $95.7^{*}$ & -12.5 \\
U1 to FH $\left(^{\circ}\right)$ & 113.8 & 117.7 & $106.1^{*}$ & -11.6 \\
IMPA $\left(^{\circ}\right)$ & 91.6 & $100.1^{*}$ & 88.6 & -11.5 \\
IIA $\left(^{\circ}\right)$ & 125.4 & $109.9^{*}$ & 132.3 & 22.4 \\
Wits $(m m)$ & -2.7 & -1.2 & $0.5^{*}$ & 1.7 \\
UL/E-L $(m m)$ & -0.8 & $3.4^{*}$ & 1.1 & -2.3 \\
LL/E-L $(m m)$ & 0.1 & $5.6^{* *}$ & 2.2 & -3.4 \\
\hline
\end{tabular}

$*$ >one standard deviation from the norm.

$* *>$ two standard deviations from the norm.

$* * *>$ three standard deviations from the norm.

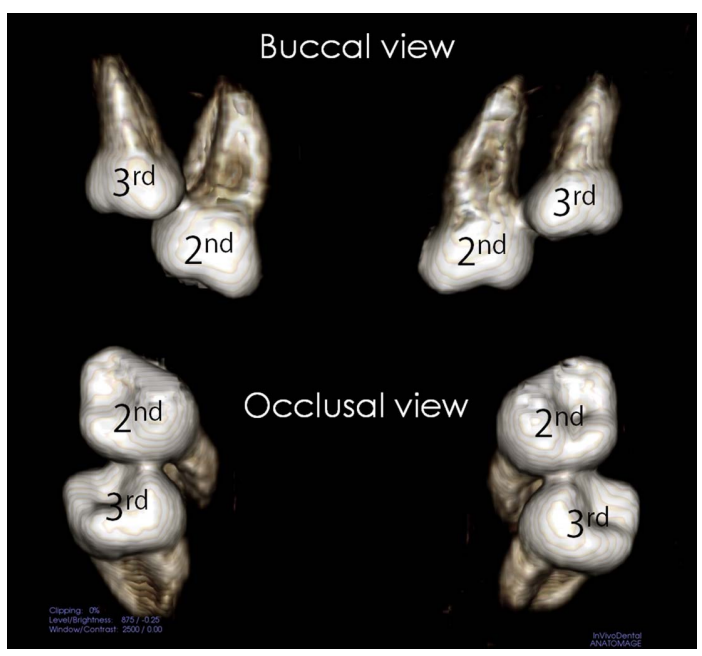

Fig. 3. CBCT images of maxillary 2nd and 3rd molars.

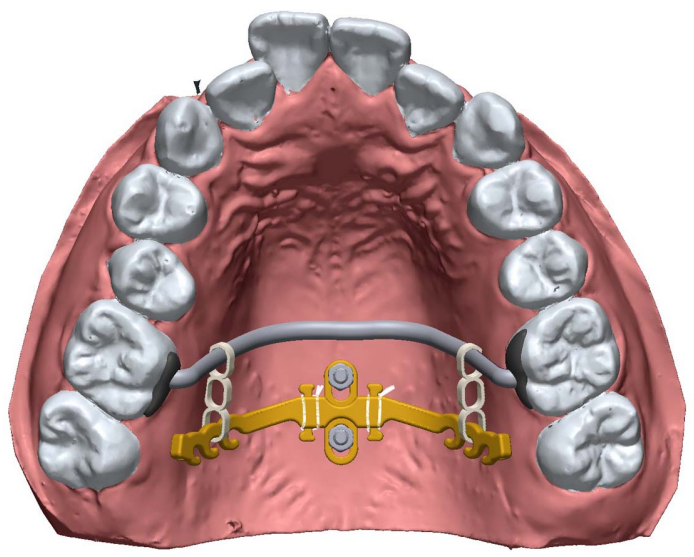

Fig. 4. LIM plate system for maxillary molar distalization.

하였다(Fig. 4).

\section{치료 경과}

치료 시작일 정중 구개부에 두개의 미니-임플랜트(LIM

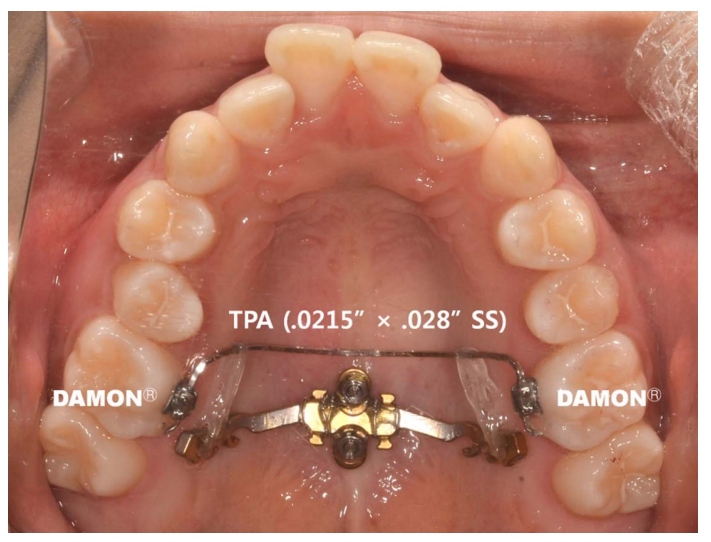

Fig. 5. Intraoral photograph at the start of treatment. Distalization forces were applied from the transpalatal arch to the palatal lever supported by mini-implants.
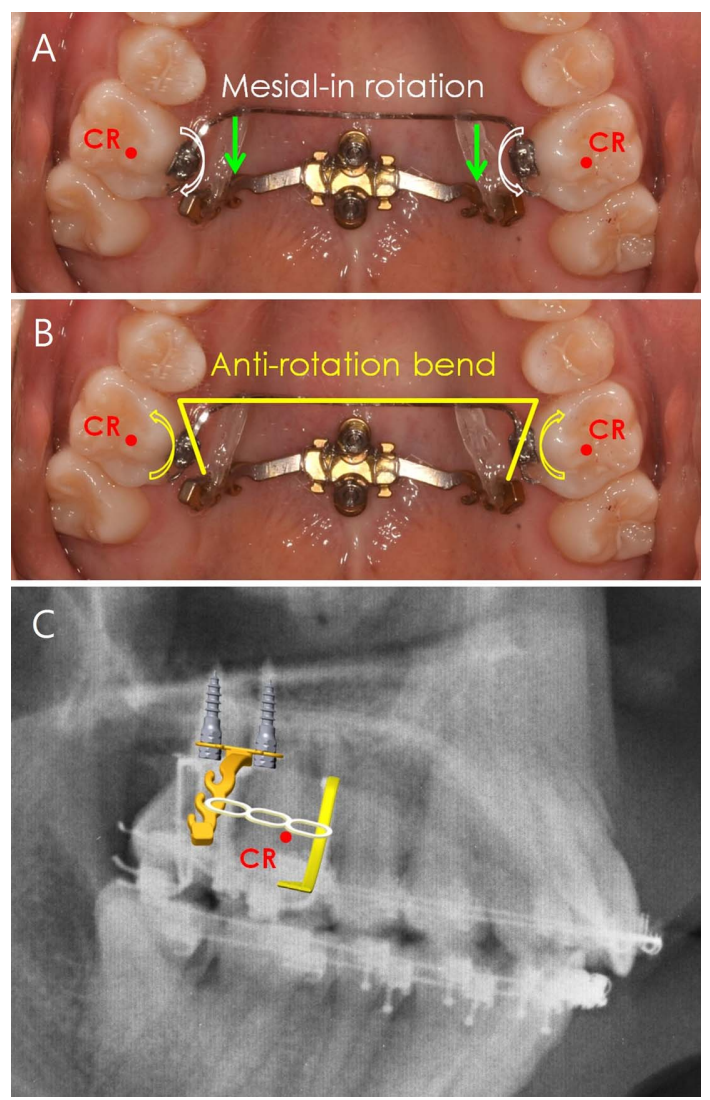

Fig. 6. Biomechanics of molar distalization system. (A) Distalization forces passing through the lingual side of the center of resistance (CR) induces moments of mesial-in rotation. (B) To negate these moments, anti-rotation bends should be bent on the transpalatal arch. (C) Distalization force was adjusted to pass through the center of resistance of first molars.

plate system, Jeil medical, Seoul, Korea)를 식립하고 레버 를 장착하였고, 상악 좌우 제1대구치 구개면에 .022" 슬롯 의 브라켓(DAMON ${ }^{\circledR}$, Ormco, Glendora, $\left.\mathrm{CA}\right)$ 을 부착하고 $.0215^{\prime \prime} \times .028 "$ 스테인리스강 횡구개호선을 연결하였다. 

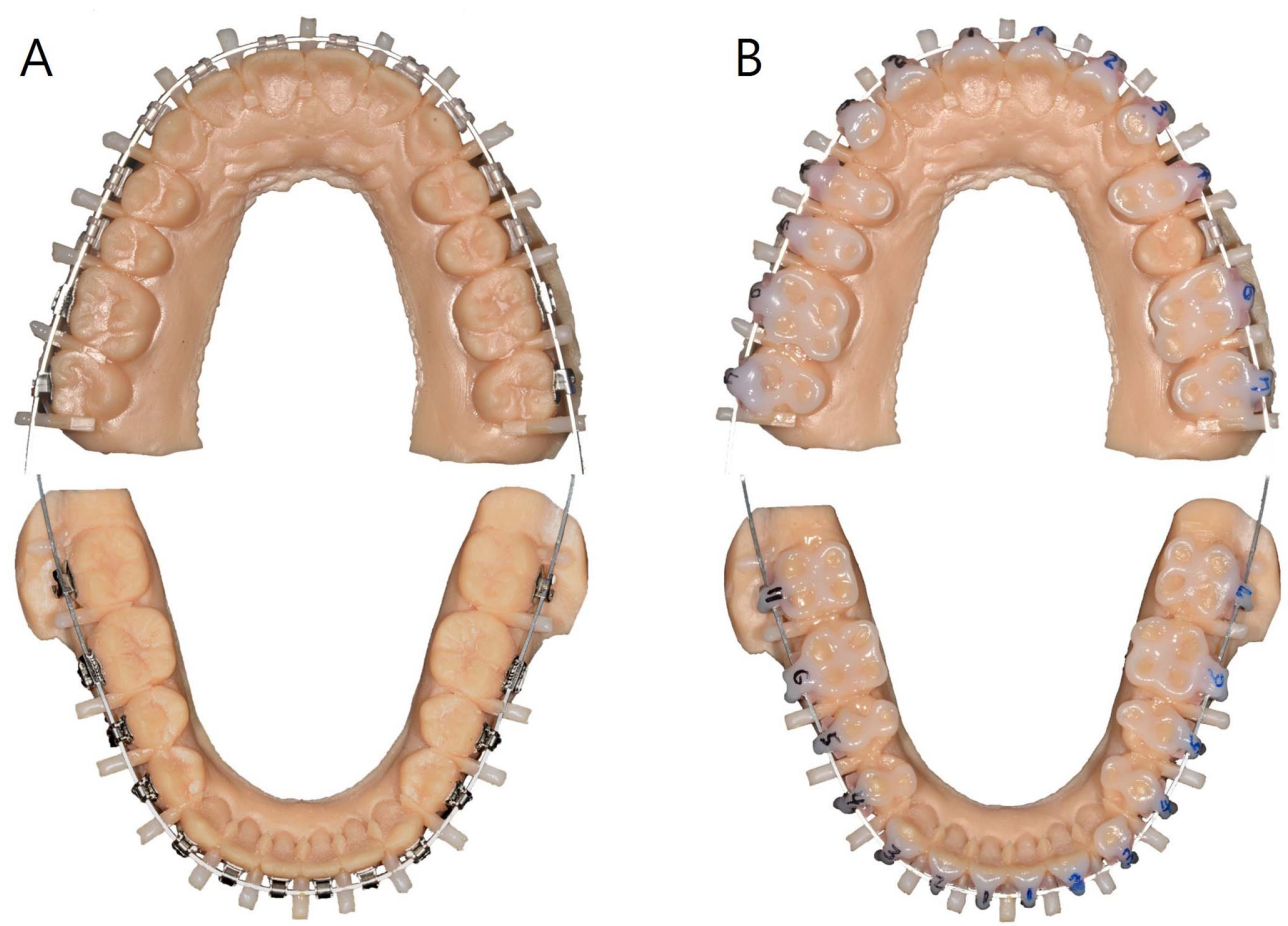

Fig. 7. Fabrication of transfer jigs. (A) Brackets were positioned on the predetermined wire plane of 3D-printed setup models. The gap between the bracket base and tooth surface would be filled with resin during indirect bonding to make custom base. (B) Transfer jigs were fabricated using flowable resin on the occlusal surface of the setup model and the bracket surface after applying paraffin wax over the occlusal wing of the bracket.

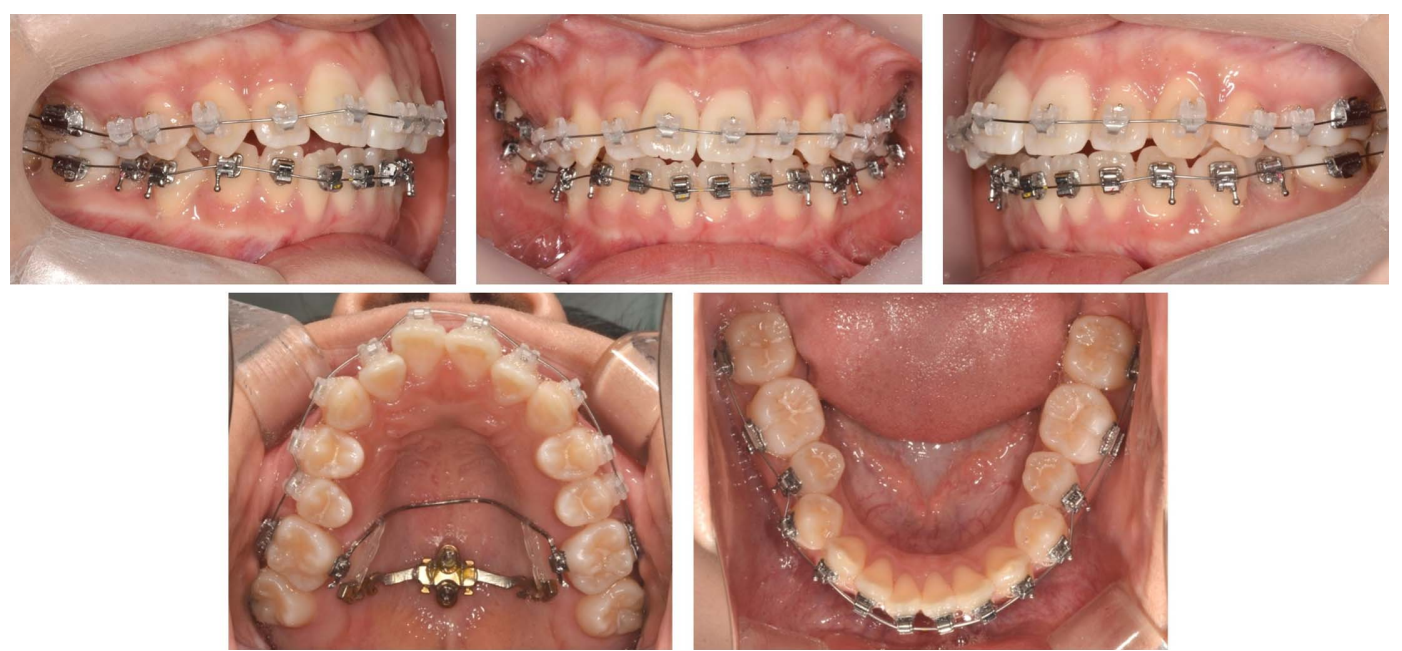

Fig. 8. Intraoral photographs at 1 month of treatment. Preadjusted .018" brackets were bonded to all teeth using transfer jigs shown in Fig. 7.

그리고 레버와 횡구개호선 사이에는 탄성 체인을 연결하 여 후방 이동을 시작하였다(Fig. 5). 이때 구개측에서 후방 력이 작용하기 때문에 제 1 대구치의 근심회전이 발생할 수 있어 횡구개호선에 anti-rotation bend를 부여하였으며 후 방력이 제 1 대구치의 저항중심을 지날 수 있도록 탄성체인 의 높이를 조정하였다(Fig. 6).

이후 치아 배열을 위해 환자의 모형을 스캔하여 디지털 셋업을 진행하였고 브라켓 위치 결정 후 간접접착술 (indirect bonding system)을 통해 장치를 부착하였다 (Fig. 7). 디지털 셋업에는 Maestro 3D Ortho Studio 2.9 (AGE Solutions, Potedera, Italy) 프로그램을 사용하였다. 브라켓은 .018" 슬롯으로 상악은 Clippy C, 하악은 Clippy metal 브라켓을 사용하였고, 초기 배열을 위해 .012" NiTi 를 장착하여 치아 배열을 시작하였다(Fig. 8).

4개월 후, 상악에는 .016" NiTi, 하악에는 .016" × .022" $\mathrm{NiTi}$ 호선을 장착하였다. 상악 우측 제 1 대구치의 경우 치 

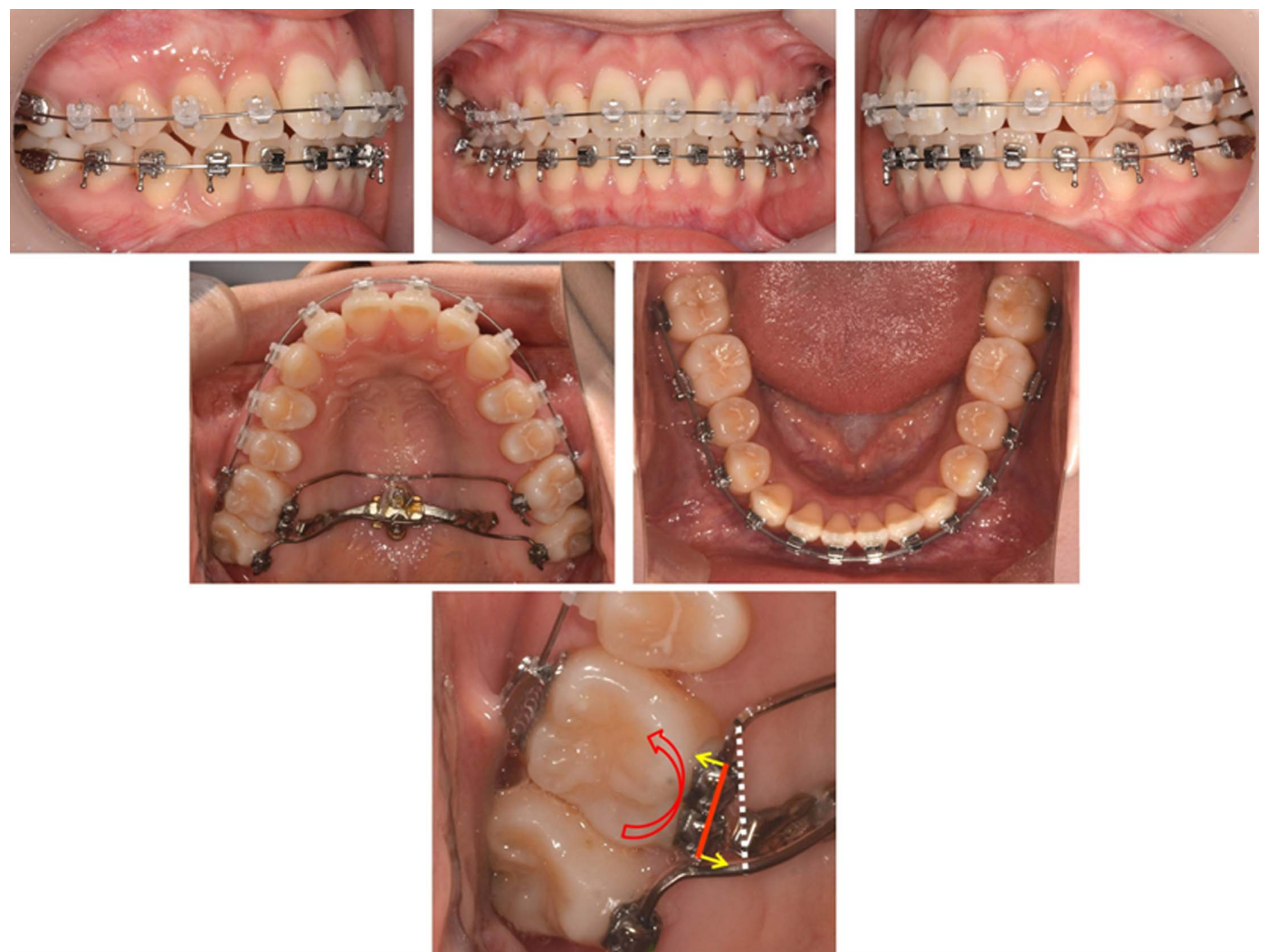

Fig. 9. Intraoral photograph at 4 months of treatment. Additional bracket was bonded on lingual surface of maxillary right first molar to increase the moment of the couple for anti-rotation.
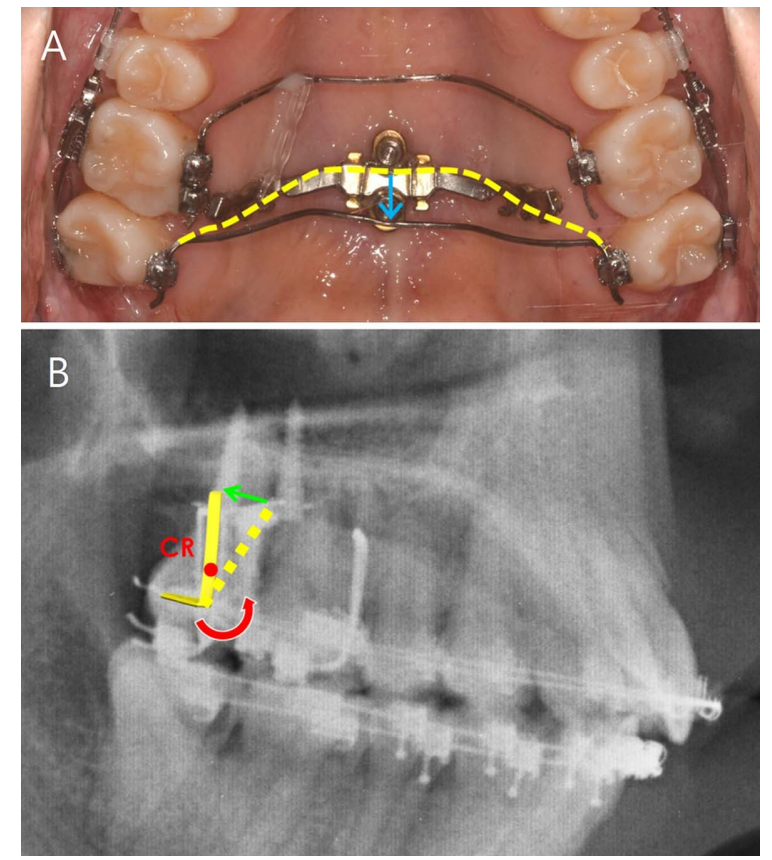

Fig. 10. (A) Transpalatal arch on maxillary second molars was hung on distal side of posterior mini-implant to generate moments for distal root movement. (B) Broken line represents passive configuration of transpalatal arch and solid line represents deformed transpalatal arch hung distal to the posterior mini-implant.
료 전부터 근심회전된 상태였기 때문에 구개면에 브라켓 을 추가로 부착하여 횡구개 호선의 원심회전 모멘트를 강 화하였다(Fig. 9).

상악 구치 후방 이동 과정에서 제 2 대구치가 원심 경사 이동을 보여, 상악 좌우 제2대구치간 횡구개호선(.021" × .025" Gummetal, RMMC, Tokyo, Japan)을 연결하고 횡구 개호선의 치근단 부위를 후방 미니-임플랜트의 후방에 위 치시켜 제 2 대구치 치근의 원심이동을 도모하였다(Fig. 10).

치료 8 개월, 상악 구치 후방 이동에 따라 전치부에 공간 이 발생하여 상악에 .016" × .022" 스테인리스강 호선을 장착하고 NiTi closed coil spring을 이용하여 전치부를 후 방견인하였다(Fig. 11).

치료 12 개월, 전치부 Bolton ratio를 개선하기 위해 상악 전치부 인접면 삭제를 시행하였다(Fig. 12). 시행 결과 전 치부 Bolton ratio는 $76.6 \%$ 로 정상범주에 들었다.

치료 18 개월, 상악 구치의 만족스러운 후방 이동으로 안 모의 개선과 $\mathrm{I}$ 급 견치 및 구치관계가 이루어져 후방 이동 을 중단하였다. 이후 마무리 과정을 진행하여 치료 시작 21개월에 치료를 종료하였다(Figs. 13 and 14).

\section{치료 결과}

전치열 후방 이동에 따라 상하순이 후퇴하여 안모의 개 

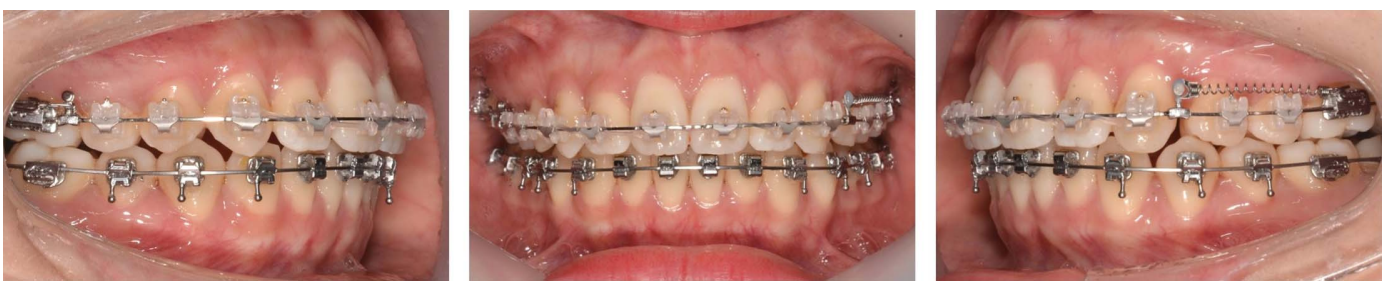

Fig. 11. Intraoral photographs at 8 months of treatment.

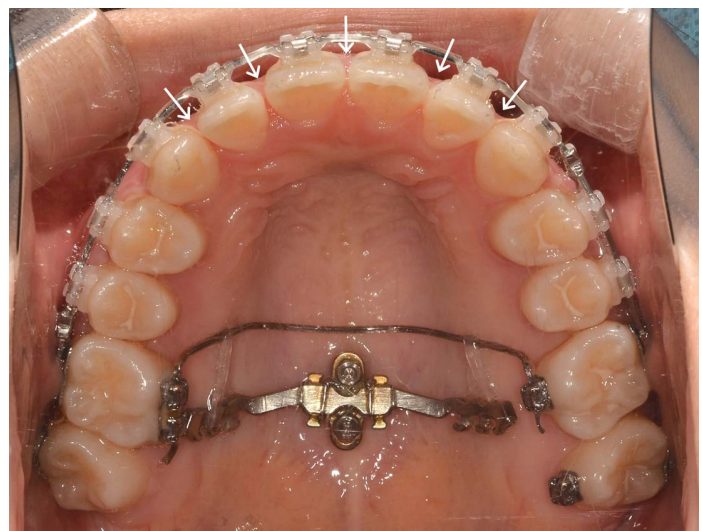

Fig. 12. Intraoral photograph at 12 months of treatment. Interproximal reproximation was performed on maxillary anteriors (white arrows).

선이 이루어졌으며, 총생이 해소되고 $\mathrm{I}$ 급 견치 및 구치관 계를 얻었다(Figs. 13-15). 측모두부계측 방사선사진 중첩 에서 상악 제 1 대구치는 $4.0 \mathrm{~mm}$ 후방 이동 하였고, 상하악 전치는 후방 경사이동이 이루어져 심미선에 대한 상하순
의 돌출도 개선되었다. 하악 과두가 후상방으로 이동하면 서 pogonion의 $1.3 \mathrm{~mm}$ 후방 이동이 나타났다(Fig. 16, Table 1).

치료 전후 $\mathrm{CBCT}$ 중첩에서 상악 제 1 대구치의 후방 이동 량을 측정한 결과, 치아 접촉점 수준에서 우측 $4.0 \mathrm{~mm}$, 좌 측 $3.5 \mathrm{~mm}$ 후방 이동하였으며 치근단 $1 / 3$ 수준에서 우측 $4.5 \mathrm{~mm}$, 좌측 $3.6 \mathrm{~mm}$ 후방이동 하였다(Figs. 17 and 18).

\section{고 찰}

미니-임플랜트를 이용한 구치 후방 이동에서 후방력은 협측 또는 구개측에서 가할 수 있다. 협측에서 후방력을 가할 경우 협측 구강 전정이 얕아 교정력이 상악 치열 저 항중심보다 교합측을 지나게 되므로 모멘트가 발생하게 되고 상악 전체 치열의 후하방 회전으로 인해서 전치부에 는 정출력이, 구치부에는 압하력이 작용하게 된다. 만약 상하악 모두에서 협측 후방력을 가하게 되면 전치부 교합

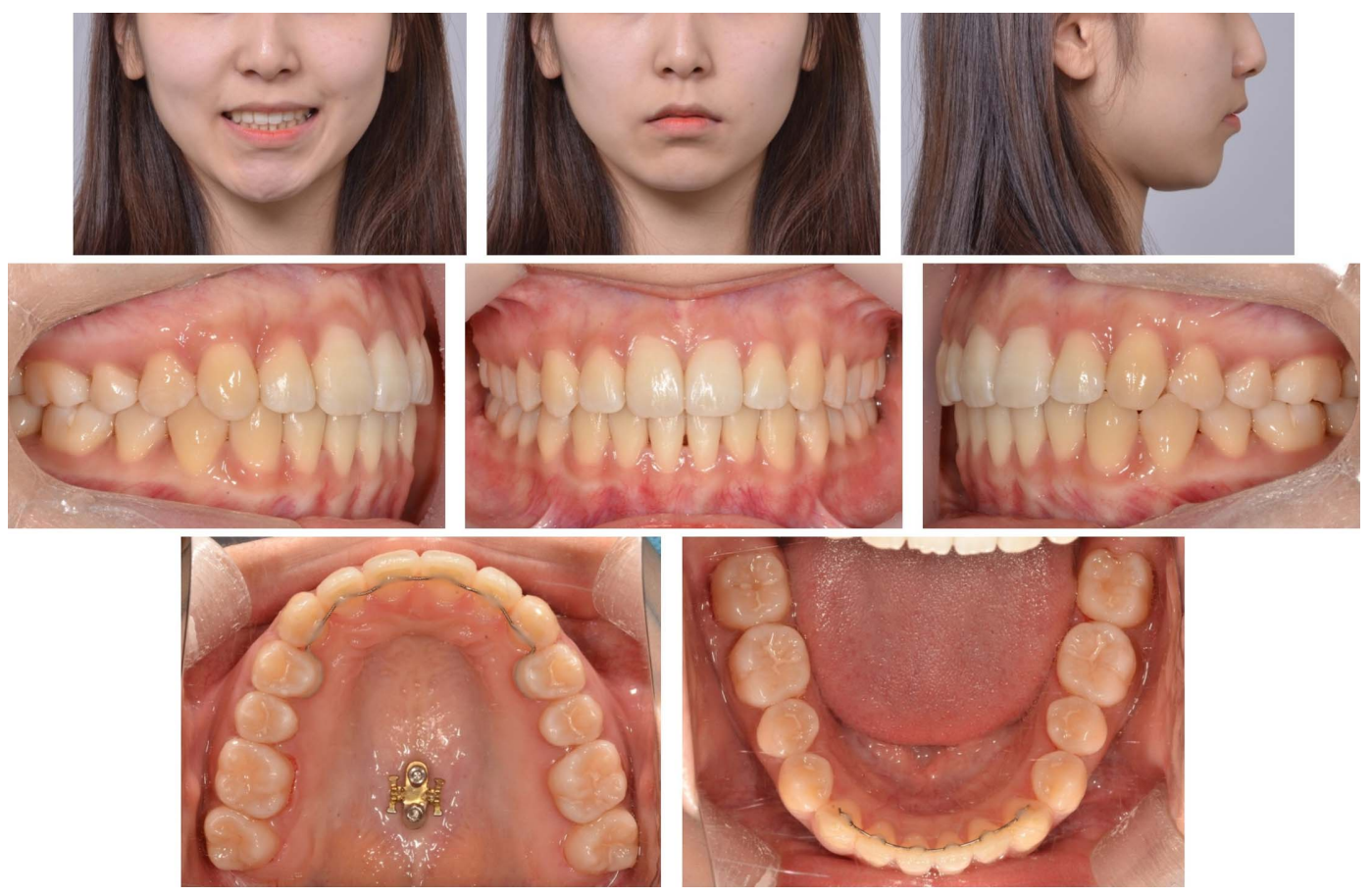

Fig. 13. Posttreatment facial and intraoral photographs. 

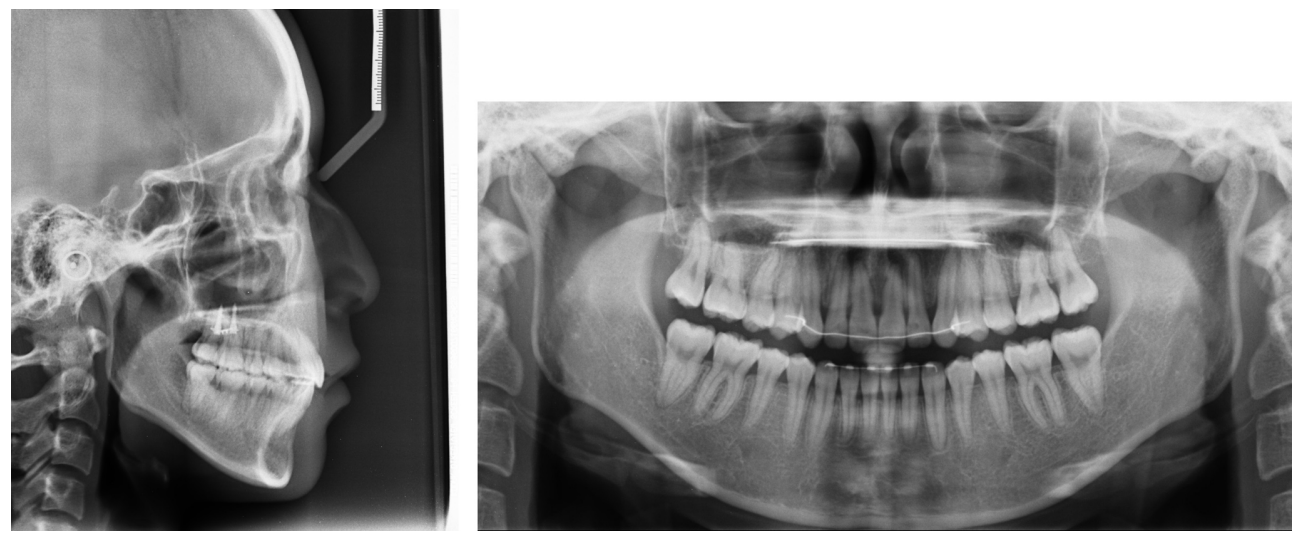

Fig. 14. Posttreatment lateral cephalometric radiograph and panoramic radiograph.
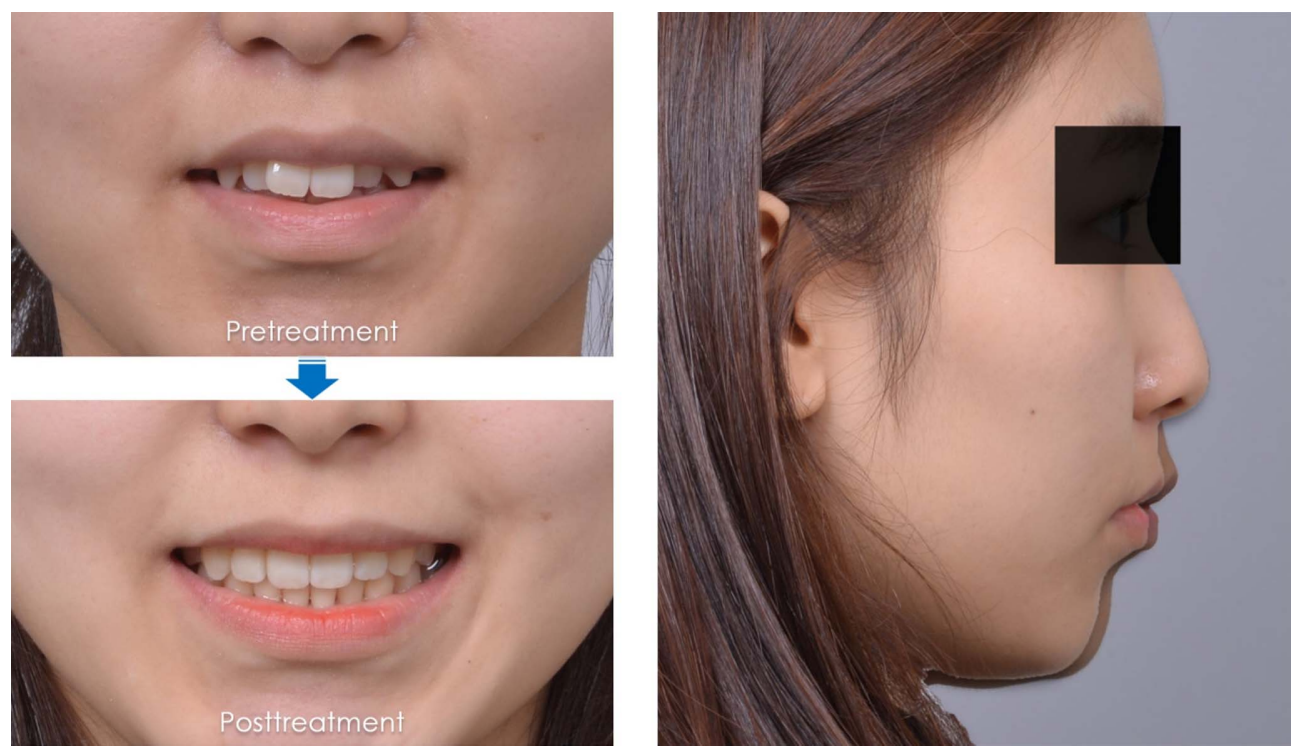

Fig. 15. Facial photographs of pretreatment and posttreatment.

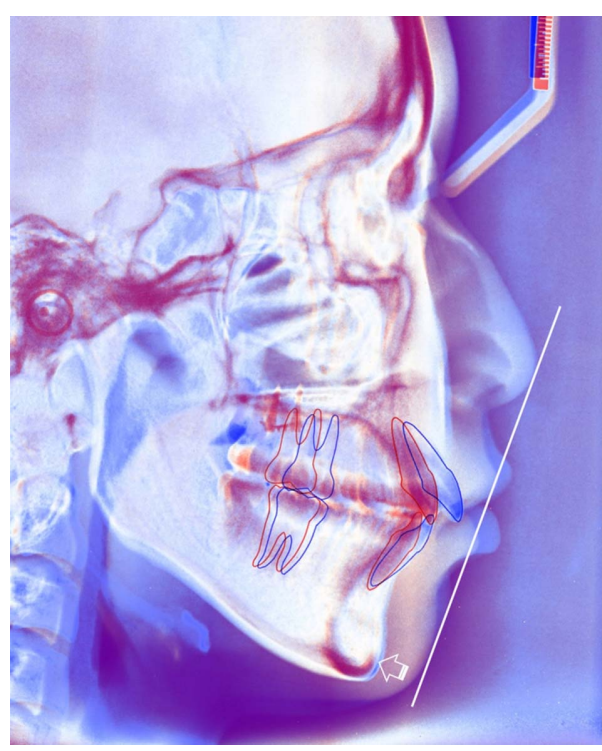

Fig. 16. Superimposition of pretreatment (blue) and posttreatment (red) lateral cephalometric radiographs.
은 깊어지고 구치부에는 개방교합이 나타날 수 있다[10]. 또한 협측 미니-임플랜트와 구개측 플레이트 고정원을 이 용한 상악 대구치의 후방 이동을 비교한 유한요소분석 연 구에서는 협측에서 후방력을 가할 경우 간접고정원과 직 접고정원 모두에서 제1대구치가 원심경사되었고 구개측 플레이트를 이용할 경우 제1대구치가 치체이동된 것으로 나타났다[12].

본 증례에서 치료 전 상악 우측 제2대구치 치근단 부위 에 상악동 함기화가 존재하였다. 치료 후 $\mathrm{CBCT}$ 시상면에 서 중첩한 사진에서 제 2 대구치 치근단 부위가 후방 이동 하면서 함기화되었던 근심 부위에 새로운 치조골이 형성 된 것을 관찰할 수 있었다(Fig. 19). 상악동 함기화가 존재 하더라도 상악동 기저부의 리모델링을 통해 치아 이동이 가능하다.

구개측에서 제 1 대구치에 후방력을 적용할 경우 제 1 대구 치의 근심회전이 발생하게 되며, 유연한 연속 호선이 장착 


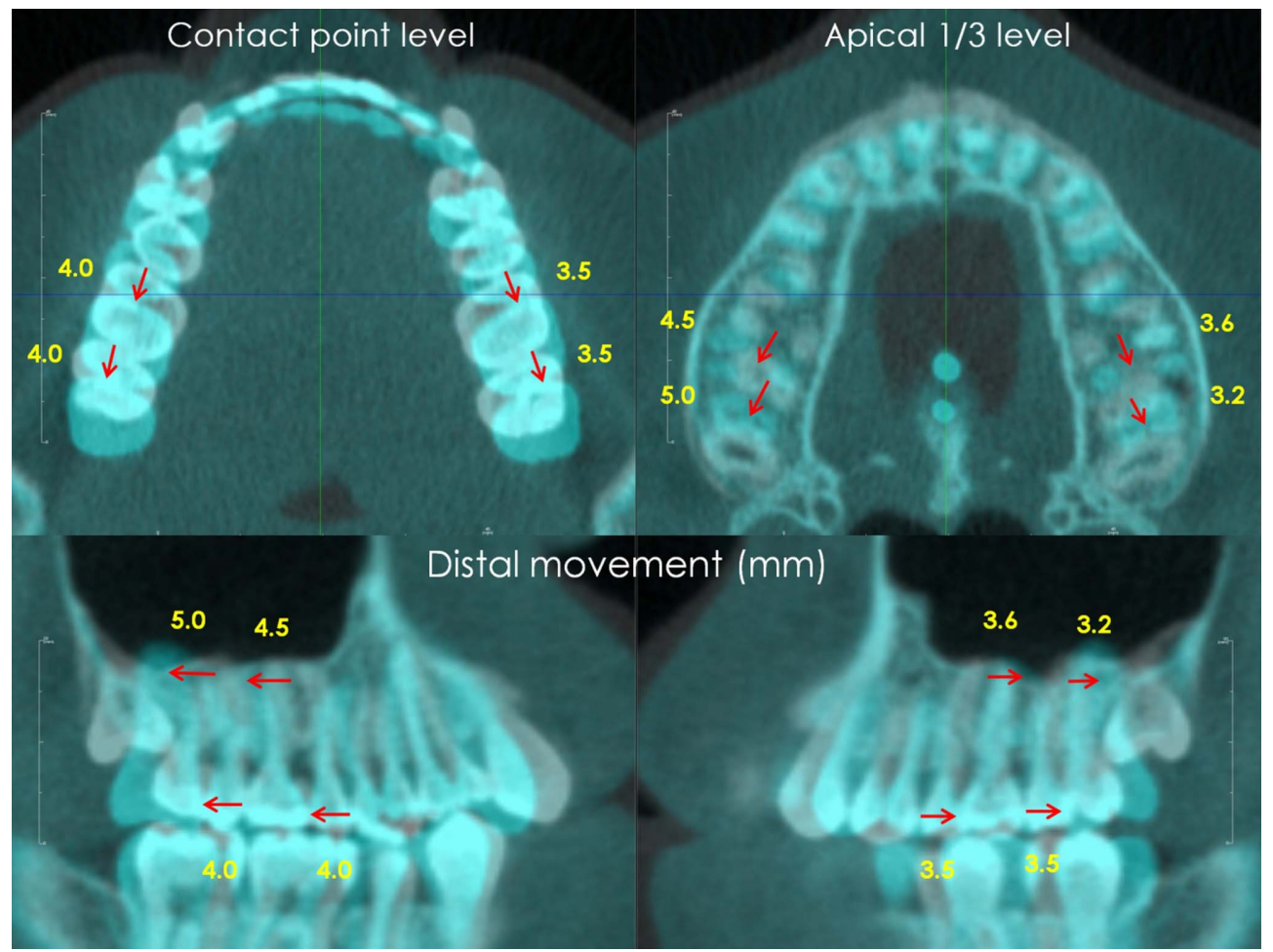

Fig. 17. Sectional views of $\mathrm{CBCT}$ superimposition of pretreatment (white) and posttreatment (blue).

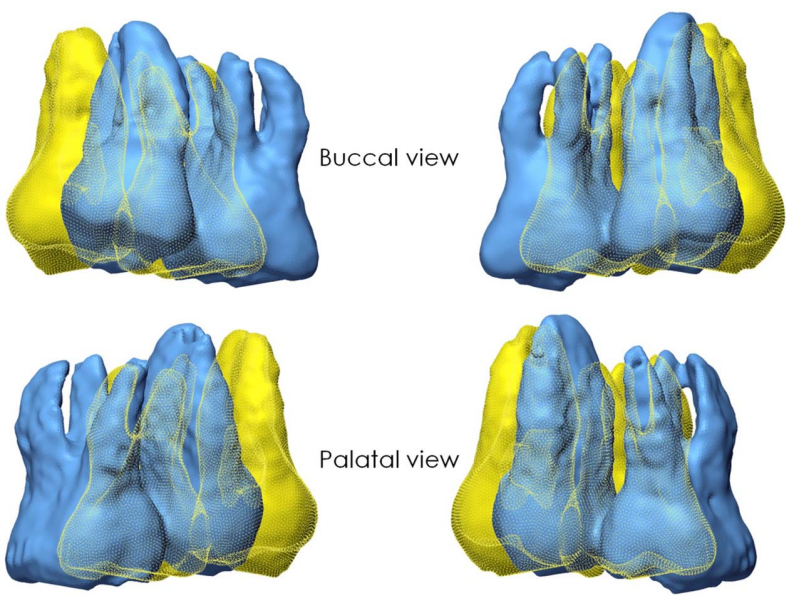

Fig. 18. Superimposition of pretreatment (blue) and posttreatment (yellow) CBCT images.

된 경우에는 이로 인해 전방부 폭경이 좁아지는 부작용이 발생할 수 있다[11]. 본 증례에서는 치료 초기부터 후방력 을 가하기 위해 견고한 스테인리스강 횡구개호선에 antirotation bend를 부여하여 근심회전을 방지하였다. 또한 협 측에서 후방력을 가하는 경우에는 주호선에 견고한 아치 와이어를 장착할 수 있을 때까지 기다린 후 후방력을 적 용해야 하지만, 구개측에 견고한 스테인리스강 횡구개 호 선을 장착하고 후방력이 치아의 저항중심을 지나도록 적 용하면 치료 시작시부터 후방력을 가할 수 있어 교정치료

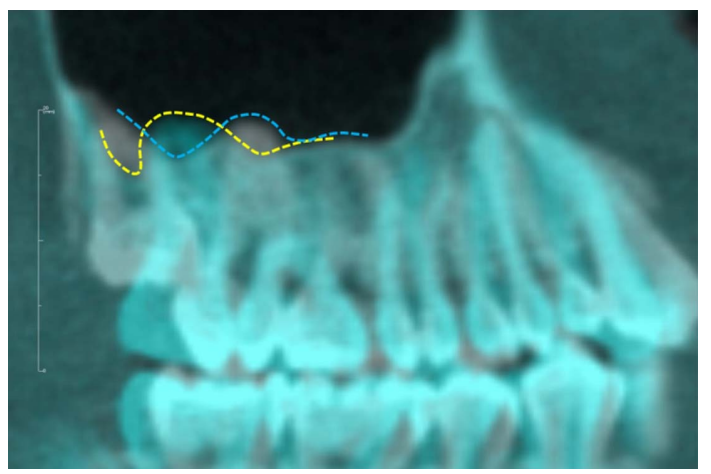

Fig. 19. Sectional views of CBCT superimposition of pretreatment (white) and posttreatment (blue). Blue break line represents pretreatment sinus floor and yellow break line represents posttreatment sinus floor.

기간을 단축시킬 수 있다.

상악 제 1 대구치간 횡구개호선을 적용하기 위해서는 구 개면에 부착된 브라켓이 필요하다. 일반적으로는 Burstone 브라켓을 band에 welding하여 사용하지만 본 증례에서는 Damon 브라켓을 직접부착하였다. 직접부착된 브라켓이 welding에 의한 것보다 탈락할 가능성이 높은 것은 사실이 지만, Damon 브라켓은 크기가 작아 이물감이 덜하며 sliding door 방식으로 호선의 착탈이 용이하다는 장점이 있다. 구치 후방이동의 경우처럼 횡구개 호선에 antirotation bend 또는 tip 조절 등이 자주 필요한 경우 유리할 
수 있다.

초진시 좌우측 구치관계가 다르거나 상악 좌우측 대구 치의 전후방적 위치에 차이가 있는 경우에는 후방이동량 을 달리할 필요가 있다. 이때에는 탄성체인의 길이나 개수 를 조절하여 좌우측 후방력의 크기를 달리하거나 한쪽에 만 후방력을 더 오랫동안 적용함으로써 후방이동량의 조 절이 가능하다.

본 증례에서는 치료시작시 구개측에서 후방력을 가할 때 제 1 대구치에만 후방력을 부여하였다. 이로 인해 제 2 대 구치의 원심 경사가 나타나게 되었고, 치료과정에서 제 2 대 구치간 횡구개호선을 장착하는 등 부가적인 조절이 필요 하였다. 후방력을 가할때 단일치아가 아니라 제1대구치와 제2대구치를 분절로 견고하게 고정하였다면, 후방 이동 시 경사이동을 줄일 수 있었을 것이다.

\section{결 론}

정중구개부 미니-임플랜트 및 횡구개호선을 이용하여 상악 치열을 후방으로 치체 이동시킬 수 있었으며, 치료 초기부터 후방력을 가함으로써 구치 후방 이동을 더 조기 에 달성할 수 있었다.

\section{감사의 글}

이 논문은 2017년도 조선대학교 치과병원 학술연구비의 지원을 받아 연구되었음.

\section{Conflict of Interest}

The authors declare that they have no competing interests.

\section{ORCID}

Chang-Bok Song 0000-0003-3711-7627

Sung-Hoon Lim 0000-0003-4528-8514

\section{References}

1. Antonarakis GS, Kiliaridis S. Maxillary molar distalization with noncompliance intramaxillary appliances in
Class II malocclusion. A systematic review. Angle Orthod 2008;78:1133-1140. doi: 10.2319/101507-406.1.

2. Park HS, Kwon TG, Sung JH. Nonextraction treatment with microscrew implants. Angle Orthod 2004;74:539549. doi: 10.1043/0003-3219(2004)074<0539:NTWMI $>$ 2.0.CO;2.

3. Keles A, Erverdi N, Sezen S. Bodily distalization of molars with absolute anchorage. Angle Orthod 2003; 73:471-482. doi: 10.1043/0003-3219(2003)073<0471: BDOMWA>2.0.CO;2.

4. Yamada K, Kuroda S, Deguchi T, Takano-Yamamoto T, Yamashiro T. Distal movement of maxillary molars using miniscrew anchorage in the buccal interradicular region. Angle Orthod 2009;79:78-84. doi: 10.2319/ 020408-68.1.

5. Mah SJ, Kim JE, Ahn EJ, Nam JH, Kim JY, Kang YG. Analysis of midpalatal miniscrew-assisted maxillary molar distalization patterns with simultaneous use of fixed appliances: A preliminary study. Korean J Orthod 2016;46:55-61. doi: https://doi.org/10.4041/kjod.2016. 46.1.55.

6. Mezomo MB, Pierret M, Rosenbach G, Tavares CAE. Extraction of upper second molars for treatment of Angle Class II malocclusion. Dental Press J Orthod 2010;15:94-105. doi: http://dx.doi.org/10.1590/S217694512010000300012.

7. Garib DG, Yatabe MS, Ozawa TO, Silva Filho OGD. Alveolar bone morphology under the perspective of the computed tomography: defining the biological limits of tooth movement. Dental Press J Orthod 2010;15:192-205. doi: http://dx.doi.org/10.1590/S2176-94512010000500023.

8. Park HS, Lee SK, Kwon OW. Group distal movement of teeth using microscrew implant anchorage. Angle Orthod 2005;75:602-609. doi: 10.1043/0003-3219(2005)75[602: GDMOTU]2.0.CO;2.

9. Kyung SH. A study on the bone thickness of midpalatal suture area for miniscrew insertion. Korean J Orthod 2004;34:63-70.

10. Jung MH, Kim TW. Biomechanical considerations in treatment with miniscrew anchorage. Part 1: the sagittal plane. J Clin Orthod 2008;42:79-83.

11. Jung MH, Kim TW. Biomechanical considerations in treatment with miniscrew anchorage. Part 2: the horizontal and transverse planes. J Clin Orthod 2008;42:144148.

12. Yu IJ, Kook YA, Sung SJ, Lee KJ, Chun YS, Mo SS. Comparison of tooth displacement between buccal miniimplants and palatal plate anchorage for molar distalization: a finite element study. Eur J Orthod 2014;36:394402. doi: 10.1093/ejo/cjr130. 